\title{
Zoando o bardo: burlescos shakespearianos
}

\author{
Marlene Soares dos Santos
}

Here goes, Horatio, - going - going - gone.

(Hamlet Travestie)

\section{INTRODUÇÃO}

No final de Hamlet (1601), o príncipe, morrendo nos braços do seu único amigo, Horácio, que ameaça se suicidar, lhe faz um emocionado pedido para que não o faça:

Absent thee from felicity awhile,

And in this harsh world draw thy breath in pain

To tell my story.

(Hamlet, 5.2.326-328)

Duzentos anos depois, mais precisamente em 1811, o príncipe se expressaria assim com a ajuda de John Poole:

If e'er you lov'd me - live - my tale to tell

And then - I care not if you go - to $\mathrm{h}$-ell.

(Hamlet Travestie, 3.6.p.69)

Se a primeira cena pede lágrimas, a segunda quer provocar o riso, já que sendo um burlesco, a sua principal preocupação é divertir. Com o grande desenvolvimento da cena teatral no século XIX na Inglaterra, conhecido como Era Vitoriana, os burlescos alcançaram o ápice do seu prestígio. Sendo Shakespeare o mais famoso dramaturgo da época, a sua obra não poderia deixar de ser a mais revisitada pelos autores de burlescos, 
destacando-se as tragédias, e entre estas, Hamlet. É a proposta deste ensaio enfatizar a importância dos burlescos em geral e a dos shakespearianos em particular, que contribuíram para a crescente popularidade da obra do Bardo rindo dele e com ele.

\section{BURLESCO / BURLETTA / TRAVESTIE / EXTRAVAGANZA}

O burlesco, também, chamado de burletta, (palavra derivada de "burla" que significa piada, ridículo, gozação), travestie e extravaganza, se originou na Itália no século XVII, como um tipo de interlúdio cômico. Apesar do termo ser usado frequentemente em relação ao teatro, ele também pode ser aplicado à literatura e à ópera, por exemplo; por isso, alguns críticos como John D. Jump (1972) usam o termo “burlesco dramático" para distingui-lo. Neste trabalho, usarei apenas "burlesco".

$O$ burlesco foi um gênero que se espalhou por toda a Europa atingindo o seu auge no século XIX, principalmente na Inglaterra e nos Estados Unidos. Entretanto, ele já existia na Inglaterra desde o final do século XVI. Shakespeare o havia apresentado em Sonho de uma noite de verão (1595-1596) com a peça dos artesãos "A tedious brief scene of young Pyramus and his love Thisbe, very tragical mirth" (5.1.56-57) [Breve cena de tédio sobre Píramo e Tisbe, seu amor; tragédia muito alegre] inspirada na história narrada por Ovídio em Metamorfoses. R.A Foakes, editor de A Midsummer Night's Dream para a New Cambridge Shakespeare registra que "The natural assumption is that Shakespeare first treated the story seriously in his tragedy [Romeo and Juliet], and afterwards exploited its possibilities for burlesque and farce in a comedy." (p.2). Outros críticos concordam com ele. No início da década seguinte, entre 1607 e 1608, Francis Beaumont (15841625) apresenta The Knight of the Burning Pestle, [O cavaleiro do pilão flamejante] um burlesco baseado nas peças de temas inspirados nos romances medievais, e componentes dos repertórios dos teatros jaimescos. Temos, assim, os dois principais alvos dos escritores dos burlescos: uma histórialpeça específica como Píramo e Tisbe, como em Shakespeare, e um tipo de drama, como em Beaumont.

As principais características dos burlescos são: simplificação e condensação dos enredos originais; transferência da ação, linguagem e 
lugar para aqueles com os quais o público está familiarizado (estratégias de localização); rebaixamento social das personagens, que falam de acordo com a sua classe; contemporaneização de eventos passados; alusões tópicas e metateatrais; uso de dísticos rimados, aliteração e ênfase nos trocadilhos; reescritura dos solilóquios como letras de canções populares ou árias de óperas; ênfase na performance teatral por meio de troca de papéis (atores para personagens femininas e atrizes para masculinos), vestuário, movimentos corporais, uso da voz e números de dança; uso da maquinaria teatral como cenografia, efeitos especiais e acessórios.

Segundo Patrice Pavis,

a escritura - ou reescritura burlesca - é uma deformação estilística da norma, uma maneira rebuscada e preciosa de se expressar e não um gênero popular e espontâneo. Ele é a marca de grandes estilos e de espíritos irônicos que admiram o objeto parodiado e apostam em efeitos cômicos de contraste e de superlativo, na forma e na temática (PAVIS, 2009, p.36, meus grifos).

Uma interrogação que paira sobre uma discussão dos burlescos é até onde o público em geral compreendia e apreciava o que estava sendo parodiado. Para Patrice Pavis, o burlesco é "uma arte refinada que pressupõe que seus leitores [espectadores] tenham uma vasta cultura e compreendam a intertextualidade." (2009, p.36). Richard W. Schoch in Not Shakespeare. Bardolatry and Burlesque in the Nineteenth Century (2006) reforça esta opinião. A postura que me parece mais correta é a de Manfred Draudt, que se opõe às de Pavis e Schoch: "Performances of travesties I have attended were enjoyed immensely by spectators who did not know the originals...But an awareness of the original adds yet another dimension to the enjoyment." (p. 308, n 24). Até onde o público compreendia e apreciava o que estava vendo dependia dos seus variados graus de competência.

Mas não se pode discorrer sobre os burlescos shakespearianos sem algumas rápidas considerações sobre os burlescos clássicos que se firmaram primeiro na cena teatral vitoriana entre 1830 e 1860.

\section{BURLESCOS CLÁSSICOS NA CENA TEATRAL VITORIANA}


O estudo dos clássicos tem uma longa trajetória na Inglaterra, principalmente depois da chegada tardia do Renascimento à ilha, no início do século XVI. E continuou marcando presença na Era Vitoriana. Segundo Simon Goldhill no seu livro Victorian Culture and Classical Antiquity: Art, Opera, Fiction and the Proclamation of Modernity

Classics was an integral part of the furniture of the Victorian mind bolstered through the elite education system, spread parodically and aspirationally through popular culture, visible in the physicality of the architecture and sculpture of the capital; disseminated in opera, in theatre, in literature, and even in battles over religion that dominated the spiritual crises that commentators loved to descry in the final years of the century. (apud MONRÓS-GASPAR, 2015: p.2)

E deve-se acrescentar ainda a influência dos jornais, das revistas e da propaganda.

A Era Vitoriana (que durou de 1837 a 1901) começou com uma Inglaterra modesta, baseada na agricultura, e terminou com a industrialização mais o vastíssimo Império Britânico se impondo ao mundo. Durante esse tempo, a sociedade inglesa sofreu várias transformações e começou a implantar outras que só seriam concluídas nas primeiras décadas do século XX. Entre as questões mais discutidas se destacava o papel da mulher nessa sociedade de regras rígidas de moral e comportamento, que resistia a se adequar às mudanças exigidas pelos novos tempos. E os burlescos clássicos, que tem a topicalidade como uma das suas caraterísticas, vão abordar de maneira ambivalente, às vezes aprovando, às vezes, não, a questão da "New Woman" que buscava mais liberdade e direitos. De qualquer modo, o universo feminino era retratado e seus problemas discutidos através das heroínas da mitologia e do teatro clássicos, muito presentes nos burlescos da época.

Alguns exemplos, retirados de uma lista dos 76 mais representativos, mostram a variedade das heroínas escolhidas:

- A'Beckett, G.A. The Three Graces: a Classical and Comical, Musical and Mythological Burlesque (1843);

- Amcotts, V. Ariadne or the Bull! The Bully! And the Bullion!!! (1870); 
- Addison, J. and Howell. Jason and Medea: a Ramble after a Colchian. A Classical Burlesque (1878);

- Brough, R.B. Medea; or the Best of Mothers, with a Brute of a Husband (1856);

- Burnand, F.C. Helen, or Taken from the Greeks (1866);

- Lemon, M. Medea; or a Libel on the Lady of Colchis (1856);

- Metcalfe, C. Hecuba à la Mode: or the Wily Greek and the Modest Maid (1893);

- Planché, J.R. The Deep Deep Sea; or Perseus and Andromeda; an Original Mythological, Aquatic, Equestrian Burletta (1833);

- Talfourd, E. Alcestis, the Original Strong-Minded Woman: a Classical Burlesque in One Act (1850);

- Talfourd, E. Atalanta, or the Three Golden Apples, an Original Classical Extravaganza (1857);

- Talfourd, E. Electra in a New Electric Light (1859);

- Wooler, J. Jason and Medea: a Comic, Heroic, Tragic, Operatic Burlesque - Spectacular Extravaganza (1857).

Deve-se notar a presença de Medéia em muitos travesties, talvez ainda sob o impacto da discussão e, finalmente, aprovação do Infants Custody Act em 1839, que garantia às mães a guarda dos filhos pequenos em caso de divórcio. Segundo Laura Monrós-Gaspar, editora da Victorian Classical Burlesques. A Critical Anthology, "reflecting the unavoidable dichotomies which permeate an exceptionally fast-changing society, classical burlesques linked arts with life, Greek tragedy with popular culture and the past with the present of women's life in Britain." (p.39).

\section{BURLESCOS SHAKESPEARIANOS NA CENA TEATRAL VITORIANA}

$\mathrm{Na}$ era vitoriana, Shakespeare alcançou o ápice do seu prestígio. Ele se encontrava presente nas galerias de arte, nas estátuas e em um prédio dedicado exclusivamente a ele: o Shakespeare Memorial Theatre, inaugurado em Stratford-upon-Avon em 1879. Além desta presença física, 
ele era encontrado em mais de 800 edições das suas peças, dirigidas a diferentes públicos como o Family Shakespeare (1807) dos irmãos Henrietta Maria e Thomas Bowdler, ou transformadas em contos para crianças como o Tales from Shakespeare publicado no mesmo ano (1807) e também escrito por irmãos - Charles e Mary Lamb -, algumas só para meninas e moças, outras só para meninos e rapazes. Ele era encontrado nas revistas, nos jornais, na literatura - poemas e romances -, na crítica e, naturalmente, nos teatros da capital e das províncias. Deve-se enfatizar que o estudo de Shakespeare se democratizou sobremaneira: foi no século XIX que se estabeleceu uma importante tradição da leitura das suas obras pela classe trabalhadora como nos mostra o livro de Andrew Murphy, Shakespeare for the People: Working-Class Readers 1800-1900 (Cambridge University Press. 2008).

Os teatros sofreram grandes modificações não só nos tamanhos, mas principalmente nas áreas de cenografia e iluminação, com cenários cuidadosamente pintados e acessórios cada vez mais tecnologicamente sofisticados, tentando alcançar o maior nível de realismo possível. Este cuidado com a encenação prejudicava o texto, que tinha de ser encurtado a fim de permitir as várias trocas de cenários. Mesmo assim, a duração de algumas peças variava de quatro a cinco horas.

O teatro vitoriano contava com as figuras de grandes atores, que eram também empresários, como William Charles Macready (1793-1873), Samuel Phelps (1804-1878), Charles Kean (1811-1868), Sir Henry Irving (1838-1905) e Sir Herbert Beerbohm Tree (1853-1917). Eles foram responsáveis por manterem as peças de Shakespeare permanentemente nos seus repertórios. Segundo Stuart Sillars, autor de Shakespeare $\mathcal{E}$ the Victorians,

At every moment, the Victorian period had Shakespearean activity of some kind at its core, and studying Victorian Shakespeare cannot be separated from studying Victorian society, and its views on history, culture, morality and ethics. If it is possible to study Shakespeare without the Victorians, it is impossible to study the Victorians without being aware of their reading, appropriation and exploitation of Shakespeare (SILLARS, 2013: p. 18). 
E quando Sillars se refere a "reading", "appropriation" e "exploitation" ele poderia estar incluindo os burlescos, ausentes no seu livro.

\section{BURLESCOS: O FAVORITISMO DE HAMLET}

Além de se inspirarem em temas e tipos de drama, como já foi mencionado, os burlescos vitorianos, em geral, parodiavam principalmente as encenações de textos shakespearianos e as performances dos atores mais famosos. Alguns burlescos sobreviventes de Hamlet podem ser citados:

- Anon. Hamlet; or, Not Such a Fool as He Looks (1882)

- Anon. A Thin Slice of Ham let! Cut for Fancy Fare (n.d.)

- Anon. Hamlet! The Ravin Prince of Denmark (1866)

- Barton [-]. Hamlet According to an Act of Parliament (1853)

- Beckington, Charles. Hamlet the Dane. A Burlesque Burletta. (1847)

- Carr, J.Comyns. Hamlet: A Fireside Hamlet (1884)

- Craig, Robert. Hamlet; or Wearing of the Black (n.d)

- Gilbert, W.S. Rosencrantz and Guildenstern. Fun (1874)

- Gordon, George L. and Anson, G.W. Hamlet à la Mode (1876)

- Poole, John. Hamlet Travestie: In Three Acts, with Burlesque Annotations (1811)

- Rice, George Edward. Hamlet Prince of Denmark; an Old Play in a New Garb (1852)

- Snow, W.R. Hamlet, the Hysterical, a Delirium in Five Spasms (1874)

- Talfourd, Francis. Hamlet Travestie (1849)

- Yardley, William. Very Little Hamlet (1884)

\section{JOHN POOLE: HAMLET TRAVESTIE (1811)}

No prefácio do seu burlesco de Hamlet, John Poole (1786-1872) explica o favoritismo de Hamlet em geral e as razões da sua escolha em particular: 
From the force of its sentiments, the beauty of its imagery, and, above all, the solemnity of its conduct, there is, perhaps, no tragedy in the English language better adapted to receive a burlesque than "HAMLET"; and from its being so frequently before the public, so very generally read, and so continuously quoted, it is, more than any other calculated to give to burlesque its full effect, and which can only be produced by a facility of contrast with its subject of work. (p.ix-x).

A peça é mais orientada para a leitura. Nas suas anotações ele critica os editores de Shakespeare, a quem chama de "authorised polluters of his text" [poluidores autorizados do seu texto] pelas explicações rebuscadas dos textos da peça. Ele faz uma exceção para Samuel Johnson (1709-1784), o primeiro grande editor e crítico de Shakespeare.

Que Poole também pensava na sua encenação (o que realmente aconteceu) pode ser provado pelo grande número de canções que permeiam a peça: vinte ao todo; geralmente solos, mas também há duetos e até um trio formado por Hamlet, Gertrudes e o Fantasma.

\section{W.S. GILBERT: ROSENCRANTZ AND GUILDENSTERN (1874)}

Tanto Richard Schoch como Stanley Wells concordam que os burlescos alcançam o seu apogeu em Rosencrantz and Guildenstern de W.S. Gilbert (1836-1911), publicado na revista Fun, em 1874, como uma reação ao grande sucesso do ator Henry Irving no papel de Hamlet no Teatro Lyceum. Ela só foi representada em 1891. O argumento é o seguinte:

To prevent Hamlet from soliloquizing, Queen Gertrude has summoned two merry knaves, Rosencrantz and Guildenstern, to provide court revels to cheer up the morose prince. When Rosencrantz and Guildenstern arrive, they learn that Ophelia is betrothed to Hamlet, who she thinks is 'idiotically sane with lucid intervals of lunacy'. The trio devises a plan to get rid of Hamlet by persuading him to perform the tragedy Gonzago before the King and his court. Unknown to Hamlet, King Claudius is the author of the ridiculous play, which was laughed off the stage opening night, and King Claudius has decreed that any reference to it is punishable by death.

Ela não só é uma paródia da tragédia e da performance do ator como também um comentário divertido sobre os seus editores e críticos:

Ophelia: Opinion is divided. Some men hold

That he's the sanest, far, of all sane men - 
Some that he's really sane, but shamming mad -

Some that he's really mad, but shamming sane -

Some that he will be mad, some that he was

Some that he couldn't be. But on the whole

(As far as I can make out what they mean)

The favourite theory's somewhat like this:

Hamlet is idiotically sane

With lucid intervals of lunacy. (First tableau)

\section{CONCLUSÃO}

Os bardólatras criticavam os autores de burlescos por desrespeitarem Shakespeare devido à maneira zombeteira e irreverente de tratarem a sua obra. Entretanto, na definição de burlesco de Patrice Pavis que citei acima, sublinhei o que ele diz: que quem escreve burlescos "admira o objeto parodiado". Esta admiração pode ser comprovada pelas palavras de John Poole no prefácio do seu Hamlet Travestie:

Whilst the beauties of poetry shall continue to delight, the works of Shakespeare will be read with enthusiasm; and any serious attempt to tarnish his fame or to degrade him from his exalted station, must ever be considered as weak and as ridiculous in the design, as it would certainly be found unavaling and impossible to the execution. (p. vii)

E no final de Romeo and Julie Travestie; or the Cup of Cold Poison de Andrew Halliday, o fantasma de Shakespeare aparece a fim de repreender os atores por terem arruinado a sua peça. Ao que a Ama responde: "you must remember, Poet, / You wrote burlesques yourself, and well you know it /In 'Midsummer Night's Dream'." (apud TAYLOR, p.141-142).

A Ama tinha toda a razão: afinal, ele não podia reclamar; foi ele quem começou... $\mathrm{O}$ que significa que os autores de burlescos vitorianos zoavam o Bardo, mas com a conivência dele.

\section{Referências}

DRAUDT, Manfred. The Real Thing? Adaptations, Transformations and Burlesques of Shakespeare, Historic and Post-Modern. In: Ilha do Desterro, nº49, jul/dez 2005, p.289-313. 
FOAKES, R.A. (Ed). William Shakespeare. A Midsummer Night's Dream.

The New Cambridge Shakespeare. Cambridge: Cambridge University Press, 2012, p. 2.

GIBERT, W.S. Rosencrantz and Guildenstern. Roteiro dramatúrgico disponível no Shakespeare Institute, Stratford-upon-Avon, RU.

JUMP, John D. Burlesque. London: Methuen \& Co. Ltd, 1972.

MARSHALL, Gail (Ed). Shakespeare in the Nineteenth Century. Cambridge: Cambridge University Press, 2012.

MATHEWS, Charles. Othello, the Moor of Fleet Street (1833). Ed. Manfred Draudt. Tübingen; Basel: Francke, 1993.

MONRÓS-GASPAR, Laura (Ed). Victorian Classical Burlesques: A Critical Anthology. London: Bloomsbury, 2015.

PAVIS, Patrice. Dicionário de teatro. Trad. J. Guinsburg e Maria Lúcia Pereira. São Paulo: Editora Perspectiva, 2009.

POOLE, John. Hamlet Travestie. With Annotations. Roteiro dramatúrgico disponível no Shakespeare Institute, Stratford-upon-Avon, RU.

$\mathrm{SCHOCH}$, Richard W. Not Shakespeare. Bardolatry and Burlesque in the Nineteenth Century. Cambridge: Cambridge University Press, 2006.

SILLARS, Stuart. Shakespeare \& the Victorians. Oxford: Oxford University Press, 2013.

TALFOURD, Francis. Macbeth Travestie. Roteiro dramatúrgico disponível no Shakespeare Institute, Stratford-upon-Avon, RU.

TAYLOR, Francis David. Shakespeare and Drama. In: GAIL, Marshall (Ed).

Shakespeare in the Nineteenth Century. Cambridge: Cambridge University Press, 2012, p.129-147.

TRUSSLER, Simon. Burlesque Plays of the Eighteenth Century. Oxford: Oxford University Press, 1969.

WELLS, Stanley. Shakespearian Burlesques. In: Shakespeare Quarterly. Vol.16, No.1 (Winter), 1965, p.49-61.

\section{Resumo}

O burlesco, também chamado de burletta, travestie e extravaganza, originouse na Itália, no século XVII, como um tipo de interlúdio cômico, 
espalhando-se por toda a Europa e atingindo o seu auge no século XIX, principalmente na Inglaterra e nos Estados Unidos. A obra de Shakespeare foi a mais revisitada pelos autores de burlescos da era vitoriana, destacando-se as tragédias, e entre estas, Hamlet. Este ensaio enfatiza a importância dos burlescos em geral, e a dos shakespearianos em particular, que contribuíram para a crescente popularidade da obra do Bardo, rindo dele e com ele.

Palavras-chave: William Shakespeare; burlesco; era vitoriana; Hamlet.

\begin{abstract}
Burlesques, also known as burlettas, travesties and extravaganzas, originate in Italy in the seventeenth century as a kind of comic interlude and spread throughout Europe, reaching their highest popularity in the nineteenth century, chiefly in England and in the United States. Shakespeare's work was the one most constantly revisited by burlesque authors in the Victorian Age, who focused on his tragedies and most frequently on Hamlet. This paper aims at highlighting the importance of the burlesques in general and the Shakespearian ones in particular, which contributed to the increasing popularity of the Bard's oeuvre, laughing at and with him.
\end{abstract}

Keywords: William Shakespeare; burlesque; victorian age; Hamlet. 